Primljen / Received: 10.7.2017. Ispravljen / Corrected: 25.10.2017.

Prihvaćen / Accepted: 9.12.2017. Dostupno online / Available online: 10.5.2018.

\section{Hydraulic-hydrology synthesis of Golubinka karst spring discharge hydrograph}

Authors:

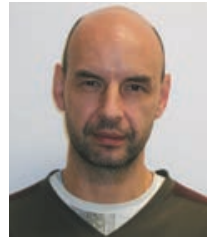

Prof. Goran Lončar, PhD. CE

University of Zagreb

Faculty of Civil Engineering

gloncar@grad.hr

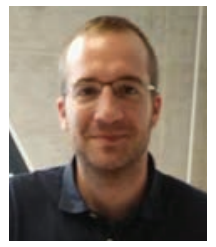

Željko Šreng, MCE

University of J.J. Strossmayera in Osijek

Faculty of Civil Engineering

zsreng@gfos.hr

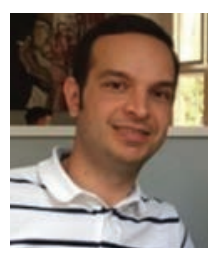

Vedran Ivezić, MCE

Hidrokonzalt projektiranje d.o.o. ivezic@hidrokonzalt.hr

\section{Goran Lončar, Željko Šreng, Vedran Ivezić}

Preliminary report

\section{Hydraulic-hydrology synthesis of Golubinka karst spring discharge hydrograph}

The hydraulic-hydrology analysis and discharge hydrograph results for the Golubinka karst spring are presented for the period from 7 September 2012 to 1 October 2013. The objective was to gain insight into processes occurring in the Golubinka spring drainage area, in terms of quantities of discharge, groundwater levels, and seepage within the karst aquifer, as related to the precipitation measured during the analysed period. An appropriate coefficient of turbulent seepage through karst channels in the analysed aquifer was determined based on two approaches. This coefficient can subsequently be used in numerical modelling.

Key words:

karst, karst channels and fractures, spring, precipitation, discharge, turbulent seepage

Prethodno priopćenje

Goran Lončar, Željko Šreng, Vedran Ivezić

\section{Hidrauličko-hidrološka sinteza hidrograma istjecanja krškog izvora Golubinka}

Prikazana je hidrauličko-hidrološka analiza i rezultati hidrograma istjecanja za krški izvor Golubinka, što obuhvaća razdoblje 7. rujna 2012. do 1. listopada 2013. Cilj je bio stjecanje uvida u procese koji se javljaju na slivnom području izvora Golubinka, u smislu količine istjecanja, razina podzemne vode i procjeđivanja unutar krškog vodonosnika, u odnosu na količinu oborina izmjerenih tijekom analiziranog razdoblja. Na osnovi dvaju pristupa određen je odgovarajući koeficijent turbulentnog procjeđivanja kroz krške kanale analiziranog vodonosnika koji se potom može koristiti u numeričkom modeliranju.

Ključne riječi:

krš, krški kanali i pukotine, izvor, oborina, istjecanje, turbulentno procjedivanje

Vorherige Mitteilung

Goran Lončar, Željko Šreng, Vedran Ivezić

\section{Hydraulisch-hydrologische Synthese des Ausflusses der Karstquelle Golubinka}

Dargestellt werden die hydraulisch-hydrologische Analyse und die Ergebnisse des Hydrogramms des Ausflusses für die Karstquelle Golubinka, was den Zeitraum vom 7. September 2012 bis zum 1. Oktober 2013 umfasst. Das Ziel war es, Einblick in die Prozesse zu erlangen, die im Wassersammelgebiet der Quelle Golubinka im Sinne der Ausflussmenge, des Grundwasserniveaus und der Filterung innerhalb des Karstgrundwasserleiters auftreten, im Vergleich zur Niederschlagsmenge, die während des analysierten Zeitraums gemessen wurde. Aufgrund zweier Ansätze wurde ein entsprechender Koeffizient der turbulenten Filterung durch die Karstkanäle des analysierten Grundwasserleiters festgelegt, der dann bei der nummerischen Modellierung angewendet werden kann. 


\section{Introduction}

During groundwater modelling in karst aquifers, any analysed area has to be studied in great detail, in order to describe hydrodispersive characteristics of the aquifer, and to define boundary conditions in terms of impermeable boundaries, springs, and sinks. Geomorphological and topographic surveys are also required in order to define recharge areas, the objective being to identify the infiltration processes. Meteorological conditions in the analysed area must also be known. Adoption of research conclusions from other areas and aquifers, and their application to the analysed area, are not advisable because of the heterogeneity of terrain in time and space [1]. All this should be kept in mind when defining the conceptual model, because simplifications and errors will undoubtedly be reflected in the numerical model. In karst, groundwater flow is mostly operated through fractures. Although the matrix may be very porous, due to its small pore size, i.e. small primary permeability, it does not greatly contribute to the flow, and so the diffuse flow operated within the matrix is often negligible. Hydraulic conductivity tends to change within a karst terrain and aquifer. It is known that the degree of karstification in carbonate sedimentary rocks generally decreases with depth. Due to recrystallization, cementation, and consolidation, the permeability of older limestones is lower compared to younger limestones [2]. When determining hydraulic conductivity of karst, attention must be paid to the "scale effect", because the conductivity differs depending on the sample volume [3]. The hydraulic conductivity of aquifer, determined by pumping test, varies between 20 and $100 \mathrm{~m} / \mathrm{d}$, which is five times greater than the hydraulic conductivity of the matrix [4]. In 1975, Mangin [5] introduced a conceptual model in which the main stream flows near the saturated and unsaturated zone interface, through an active system of fractures and karst channels. This main fracture system transmits water towards the karst spring, and is weakly associated with other large voids in adjacent rock. This is referred to as an "annex to the drainage system". He also introduced the concept of a shallow, highly permeable zone below ground surface, called epikarst, that temporarily stores precipitation, and drains it to vertical shafts, thus enhancing the concentrated infiltration. When calculating the underground flow, it is easiest to apply the Darcy"s equation and assume that porous media all behave similarly at a representative scale [6]. This method is called an equivalent porous medium approach. The hydraulic head measurement in karst aquifer and its interpretation is often nonuniform and so this information is insufficient for the assessment of groundwater flow. Also, it is very difficult to determine main quantities of Darcy"s equation due to various levels of porosity that govern the flow (matrix porosity, micro and macro fractures, solutional cavities). Therefore, in order to obtain a realistic value of groundwater flow, it is necessary to integrate the Darcy"s equation of laminar flow through rock matrix with hydraulic equations of turbulent flow through sets of fractures, pipes and channels, and to combine hydraulic head measurements with other field tests, such as dye tracing.
In this research we were forced to deal with the lack of information about the analysed catchment area. The location of fractures and preferential flow paths were not fully obtained or known. No information was available regarding the underground water levels, with the exception of research provided by the IGH institute in 2013, when exploratory drilling was performed in the analysed catchment area. The main objective of this research is to obtain a discharge hydrograph for the Golubinka karst spring, and to determine the groundwater level hydrograph and seepage quantities within the aquifer of the Golubinka catchment area, despite the scarcity of in-situ measurements, using inherent assumptions and hydraulic equations. The input data for this research were the precipitation data obtained from a nearby ombrograph station, and the data from the water level recording station located at the Golubinka Spring. The analysis was performed over a period of 389 days. Using the water level data, the difference between the sea and the groundwater level was determined, which was used to create the discharge hydrograph for the Golubinka Spring. The linear relationship between the water level difference and the discharge was assumed. It was also assumed that the total infiltrated volume of precipitation equals the total volume of discharge at the Golubinka Spring. This allowed us to analyse this area as a closed system, in which the Golubinka Spring is the only place of discharge. We also introduced a second approach for determining the spring discharge quantities, proposed by Bear in 1979 , in which the precipitation is the only basic input parameter. After that, our goal is to simulate groundwater level at the reference position for the same period, with a simple approach based on the continuity equation. In the end, calculations of the turbulent seepage through the Golubinka catchment area will be conducted, using the results from previous calculations, i.e. spring discharge quantities and groundwater levels. Non-linear Manning equation will be used for calculating turbulent seepage through fracture system of the Golubinka Spring catchment area, and turbulent seepage coefficient $\left(k_{t}\right)$ will be the main outcome of this calculation. This coefficient will later on be used in numerical modelling of the analysed aquifer.

\section{Study site}

The research area is located between the Adriatic microplate in the southwest and the Dinaric regional structural unit in the northeast. Their contact is represented by reverse faults of the northeastsouthwest strike [7]. The Eocene and Cretaceous limestones are the main component of the terrain $[8,9]$. The Golubinka Spring is a typical karst spring, mostly composed of Cretaceous and Paleogene limestones, with local occurrences of dolomite. Visible channels and caves at the location of the Golubinka Spring and adjacent springs (Pod Gredom Spring and Šušnjara Spring) point to the presence of typical karst flow conditions. The catchment area of the Golubinka Spring (Figure 1) is an integral part of a wider catchment that covers the entire hinterland of the city of Zadar, called Bokanjac-Poličnik. Hydro-geologically, the catchment of the Golubinka Spring can be separated from the rest of the Bokanjac-Poličnik catchment area by a zonal underground water divide, which is unfortunately not fully known. In the coastline area, the carbonate rocks are in contact with 
sea water in a narrow area, as flysch formations in Ljubački bay act as an undersea barrier. Groundwater can thus suppress intrusion of sea water until the end of the summer, when the aquifer level and discharge drops. Another groundwater barrier is located to the southwest of the Golubinka Spring, where a five-meter thick layer of residual soil is present [10]. However, some water passes under it and runs towards the Bokanjac Spring. Morphologically, the catchment area is dominated by karst fields and small hills, the highest peaks being at $120 \mathrm{~m}$ a.s.l.. The terrain of the catchment area is shaped by several anticlines and synclines [11]. In most cases, the groundwater flows in the northwest direction in this catchment area. There is an underground connection between the sink in Biljanje Donje (Figure 1) and the Golubinka Spring where the flow velocities of up to $8.1 \mathrm{~cm} / \mathrm{s}$ have been registered [11]. This is confirmed by the groundwater level near the Oko Spring (Figure 1), with an elevation of $60 \mathrm{~m}$ a.s.l., which represents a significant groundwater gradient towards the Golubinka Spring [11].

At the Golubinka Spring water surfaces about 15 meters from the coast, at an elevation of less than one $\mathrm{m}$. The vicinity of the coast causes intermittent intrusion of sea water in the aquifer near the spring site. This intrusion is more pronounced in summer months when the water level in the aquifer decreases, in accordance with spring discharge. This phenomenon varies from year to year, depending on the amount of precipitation in the area and, because of its rapid response to rainfall, the discharge suddenly increases and the water rapidly becomes fresh once again. According to [12] where a 30-year period was analysed (1961-1990), the largest discharge took place in February with an average flow rate of 1000 $\mathrm{l} / \mathrm{s}$. The lowest discharge was registered in July, with an average flow rate of $100 \mathrm{l} / \mathrm{s}$. The average annual discharge and rainfall amounted to approximately $417 \mathrm{l} / \mathrm{s}$ and $992 \mathrm{~mm}$, respectively. The partition wall was built at the Golubinka Spring itself where the

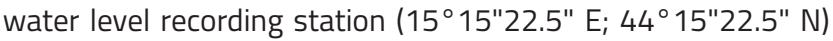
was set up, and where the water level difference between the "sea" and "freshwater" side of the partition wall was measured (Figure 1). A schematic diagram of the Golubinka Spring with the partition wall is shown in the Figure 2. The precipitation data were measured at the ombrographic station at the Zadar

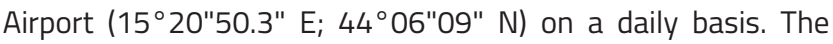
collection area of the ombrograph is $200 \mathrm{~cm}^{2}$. The ombrograph accuracy is $\pm 0.1 \mathrm{~mm}$ or $\pm 1 \%$ at the precipitation of $<6 \mathrm{~mm} / \mathrm{min}$ and $\pm 2 \%$ at the precipitation of $>6 \mathrm{~mm} / \mathrm{min}$, and the intensity accuracy is $\pm 0.1 \mathrm{~mm} / \mathrm{min}$.

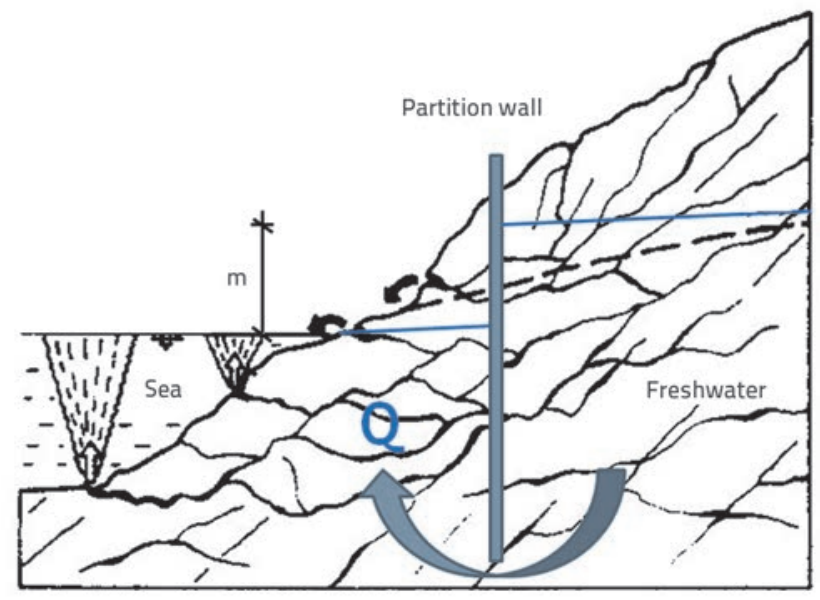

Figure 2. Partition wall at the Golubinka Spring

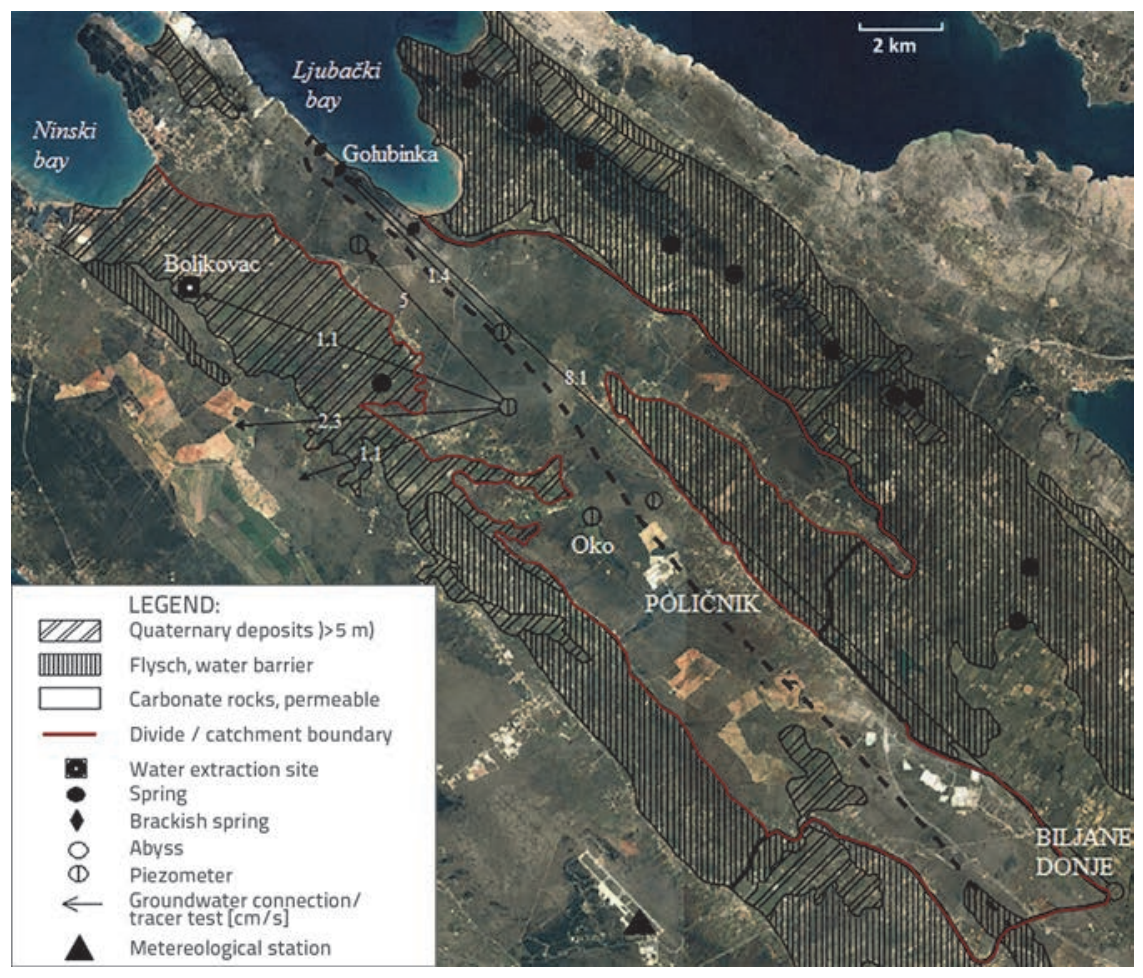

Figure 1. Schematic hydrogeological map of the Golubinka Spring catchment area

\section{Settings and results of karst aquifer seepage model}

The available daily water level data on the difference between the "sea" and "freshwater" side of the partition wall $(m)$, and the daily precipitation data from the ombrographic station at Zadar Airport, are shown in Figure 3. It should be noted that the water level data do not relate to the overhead height of the calibration flume, but only to the height above the sea level at the spring near the sea. Accordingly, there is no reliable hydrograph $Q(\mathrm{t})$ for the Golubinka Spring. If it is assumed that the analysed period ( $7^{\text {th }}$ September $2012-1^{\text {st }}$ October 2013 , 389 days) represents a hydrological cycle after which the groundwater volume is equal to the one registered at the beginning of the observed period, and that the Golubinka Spring is the only relevant position for the "discharge" of the 


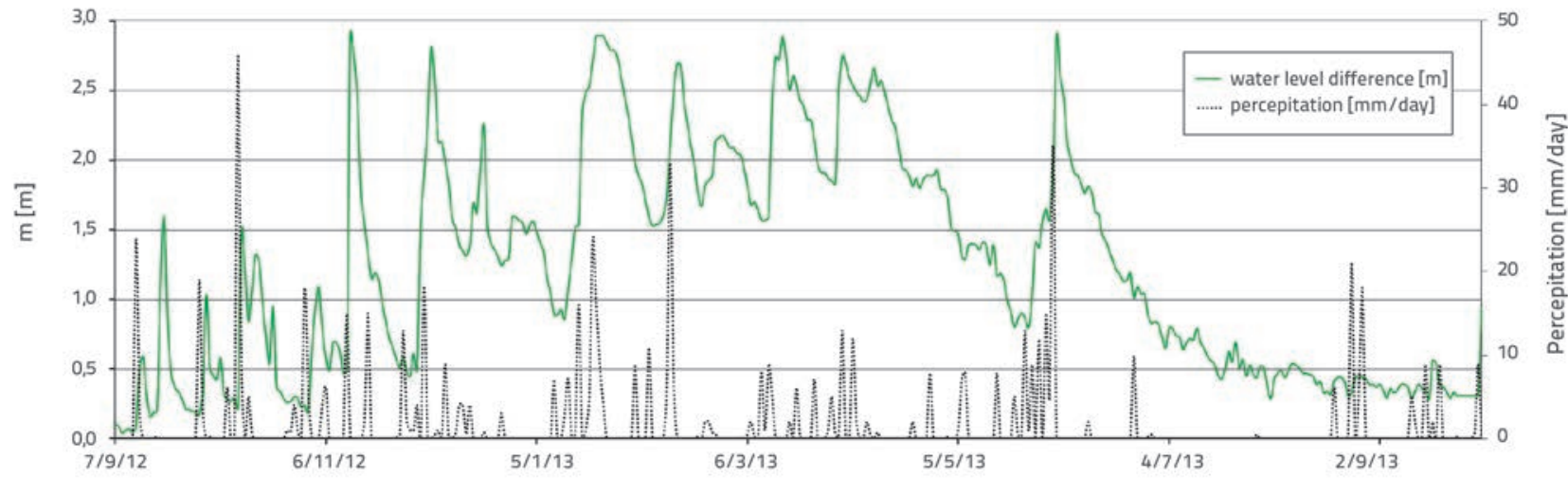

Figure 3. Water level data on the difference of water levels between the "sea" and "freshwater" sides of the partition wall and precipitation data from the ombrographic station at Zadar Airport

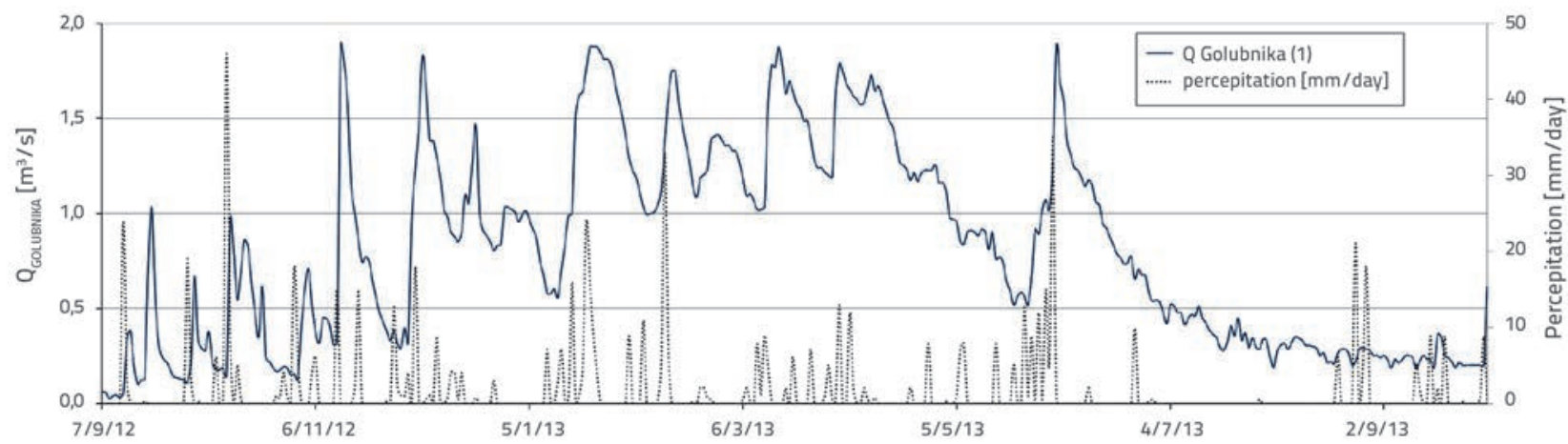

Figure 4. Discharge hydrograph for the Golubinka Spring in the analysed period

catchment, then the total infiltrated volume of precipitation at the catchment corresponds to the total discharge at the Golubinka Spring $\left(V_{\text {infitrated }}\right.$ precipitation for 389 days = mean spring discharge $Q_{\text {mean }} \cdot 389$ days $\cdot 86400 \mathrm{~s}$ ). The linear relation between the spring discharge and the water level difference $(m)$ is assumed, $Q_{\text {Golubinka }}$ $=k_{m} \cdot m$, where $k_{m}$ represents the linear relation coefficient. The spring discharge is obtained by Darcy"s equation where the area $(A)$, hydraulic conductivity $(k)$, and length $(L)$ represent calibrated parameters, and the value of height $(h)$ from Darcy"s equation corresponds to the height $m$. The adoption of this hypothesis, assumptions, and the data for the surface of the catchment $R=$ $65 \mathrm{~km}^{2}$ [11] and infiltration coefficient $\gamma=0.6$ [13], yields a linear correlation between the $Q_{\text {Golubinka }}$ flow rate and the water level difference $(m) Q_{\text {Golubinka }}(t)=f(m)=0.65 \cdot m$. The resulting hydrograph obtained using this approach (approach 1) is shown in Figure 4. The average discharge rate for the analysed period is $810 \mathrm{l} / \mathrm{s}$, which is two times greater than the value given in [11]. Higher discharge values arise from the assumption that the Golubinka Spring is the only relevant spring in the area. These results can therefore represent a cumulative discharge from that area.

A simple approach based on the continuity equation was used to define the groundwater level for the same period, Eq. (1) [14]. The assumption was that the groundwater level at the position of Oko piezometer (Figure 1) represents the reference value for the entire catchment.
$\mathrm{H}_{\mathrm{t}+\Delta \mathrm{t}}=\mathrm{H}_{\mathrm{t}}+\left[\left(-\mathrm{Q}_{\text {GOLUBNIKA }}-\mathrm{Q}_{\mathrm{PUMP}}+\gamma \times \mathrm{P} \times \mathrm{R}\right) / \mathrm{S} \times \mathrm{R}\right] \cdot \mathrm{Dt}$

where:

$H_{t}, H_{t+\Delta t}$ - the groundwater levels [L] at the beginning and the end of the calculation step

$Q_{\text {GoLUBINKA }}$ - the discharge flow at the Golubinka Spring [ $\left[\mathrm{L}^{3} \mathrm{~T}^{-1}\right]$

$Q_{\text {PUMP }} \quad$ - the pumping rate $\left[\mathrm{L}^{3} \mathrm{~T}^{-1}\right]$

$\gamma \quad$ - the infiltration coefficient [-]

$R \quad$ - he area of the basin $\left[\mathrm{L}^{2}\right]$

$S \quad$ - the storage coefficient [-].

The initial groundwater level (initial condition) had to be adopted for the calculation based on groundwater level measurements

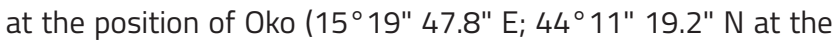
altitude of $55 \mathrm{~m}$ [15]), as conducted on 29.9.2013 when the groundwater level was at $49.5 \mathrm{~m}$ a.s.l. Therefore, the initial groundwater condition ( $7^{\text {th }}$ September 2013) was reached by making calculation on $29^{\text {th }}$ September 2013 and obtaining the measured value of $49.5 \mathrm{~m}$ a.s.l., with the adopted values of the infiltration coefficient $\gamma=0.6$, catchment area $R=65 \mathrm{~km}^{2}$, and storage coefficient $S=0.01$ [15]. Furthermore, the data from [17, 18] show that the mean groundwater level for the period 19661968 amounted to $52 \mathrm{~m}$ a.s.l. at Oko locality, which corresponds to the values obtained through calculation according to this approach (Figure 5). 


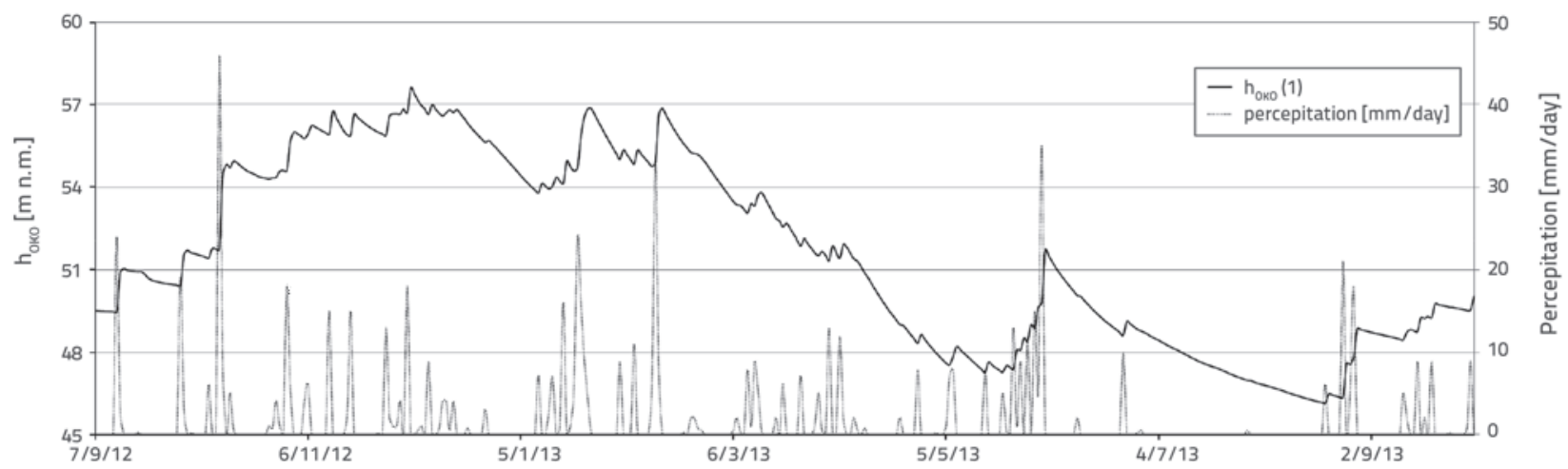

Figure 5. Groundwater levels in the analysed period at Oko piezometer (calculation based on results according to Approach 1)

Groundwater seepage through the Golubinka Spring catchment area is described below. Given the specificity of seepage into the karst aquifer, it should be noted that Darcy"s law in linear form is valid when the critical Reynolds number is below 1 . The transient and turbulent flow develops at values above 1. In such cases the resistances are nonlinear, and the slope of piezometric height is expressed in the form of $/ \mu v^{n} . n=2$ is adopted for turbulent flow, and the corresponding seepage law is: $v=k_{t}$ sqrt (I), where $k_{t}$ is the turbulent seepage coefficient. Groundwater seepage through the Golubinka Spring catchment takes place in a non-uniform fracture system, with changes of conductivity along the flow axis. At that, most of the seepage is operated through karst channels, while some water also passes through fissures adjoining such channels. Darcy-Weisbach"s or Manning equation for velocity estimation can be used to calculate turbulent seepage through the fractures. The relative conductivity function assumes the following form (for the Manning equation for flow): $Q(y)=K(y)$ sqrt(I), where $K(y)$ is the relative cumulative conductivity function. The non-uniform fracture system is represented by a fracture/ channel in which the conductivity changes along the flow axis, where the mean conductivity value is equal to the arithmetic mean between the conductivity at the edges of the section, piezometer Oko on the one side, and the Golubinka Spring on the other. The conductivity was calculated using the following expression: $K=k_{t} \cdot A$, where $A$ is the cross section of the aquifer, $A$ $=h \cdot W$, where $h$ corresponds to the groundwater level obtained in the previous step of the calculation, and $W$ corresponds to the geometry of the catchment.

$\bar{K}=\frac{K\left(I_{1}, h_{1}\right)+K\left(I_{2}, h_{2}\right)}{2}$

$h_{2}-h_{1}+\frac{|Q| Q}{\bar{K}^{2}} L=0$

where: $\bar{K}$ is the arithmetic mean of the hydraulic conductivity [ $\mathrm{LT}^{-1}$, $K\left(I_{1}, h_{1}\right)$ i $K\left(I_{z^{\prime}} h_{2}\right)$ are hydraulic conductivities $\left[\mathrm{LT}^{-1}\right]$, $L$ is the distance between the edges of the section $[\mathrm{L}], h_{1}$ is the groundwater level at the Oko $[\mathrm{L}], h_{2}$ is the groundwater level at the Golubinka Spring $[\mathrm{L}]$, and $Q$ is the seepage within the aquifer $\left[\mathrm{L}^{3} \mathrm{~T}^{-1}\right]$.
The time series of seepage quantities through the Golubinka catchment area was obtained by using Eqs. (2) and (3), by varying the coefficient $k_{t^{\prime}}$ and by adopting the values: $L=10 \mathrm{~km}$ (the distance Oko - Golubinka Spring, Figure 1), $W_{\text {oko }}=2000$ $\mathrm{m}$ (aquifer width at the Oko position), $W_{\text {Golubinka }}=250 \mathrm{~m}$ (aquifer width at the Golubinka Spring position), $h_{1}(\mathrm{t})$ from Figure 5, and $h_{2}$ (t) from Figure 3 (Figure 6). In this calculation, coefficient $k_{t}$ represents the calibration parameter and the results presented are obtained using the $k_{t-0 k o}=1.0 \cdot 10^{-6} \mathrm{~m} / \mathrm{s}$ (for the Oko position) and $k_{t \text {-GOLUBINKA }}=7.3 \cdot 10^{-2} \mathrm{~m} / \mathrm{s}$ (for the Golubinka Spring position). The goal was to obtain results similar to those obtained in the first step, in relation to the amount of seepage and discharge from the Golubinka Spring.

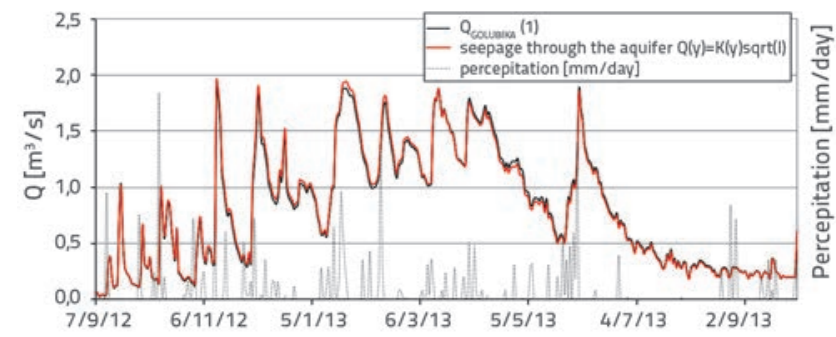

Figure 6. Time series of seepage through Golubinka catchment (groundwater flow in the aquifer) and discharge at Golubinka Spring (Approach 1)

The Approach 2 is based on the linear mathematical model for spring flow presented in [19]. In this approach, the precipitation is the basic input parameter, and the flow domain is hydrologically divided into two parts, the recharge zone and the transmission zone, as can be seen in Figure 7. The depth $h_{2}(t)$ at the place of discharge is represented by the height of the cover $m$, and $h_{1}$ $(t)$ in the recharge zone is obtained by calculation. In addition, the following values: $L=24 \mathrm{~km}$ (recharge length), $W r=2700 \mathrm{~m}$ (recharge width), I= $750 \mathrm{~m}$ (transmission length), $W \mathrm{~s}=250 \mathrm{~m}$ (spring width), $f i_{1}=0.01$ (specific yield), $k=2.9 \cdot 10^{-2} \mathrm{~m} / \mathrm{s}$ (filtration coefficient on the aquifer scale), were also used in calculation. Values $L$ and Wr correspond to the geometry of the catchment (Figure 1). Values / and Ws vary (calibration parameters of the 
model), the objective being to obtain the summary discharge for the analysed period as in the case of the previous approach. The adopted value $\mathrm{fi}_{1}$ is the same as the storage coefficient $S$ from the previous approach. The $k$ value is obtained by exploratory works on the spatial scale of test wells and amounts to $2.9 \cdot 10^{-4}$ $\mathrm{m} / \mathrm{s}[17,18]$. Considering that the relation $k$ on the spatial scale of the aquifer and test wells » 100 [4], the value $k=100 \cdot 2.9$ . $10^{-4} \mathrm{~m} / \mathrm{s}=2.9 \cdot 10^{-2} \mathrm{~m} / \mathrm{s}$ was adopted for the needs of the calculation.

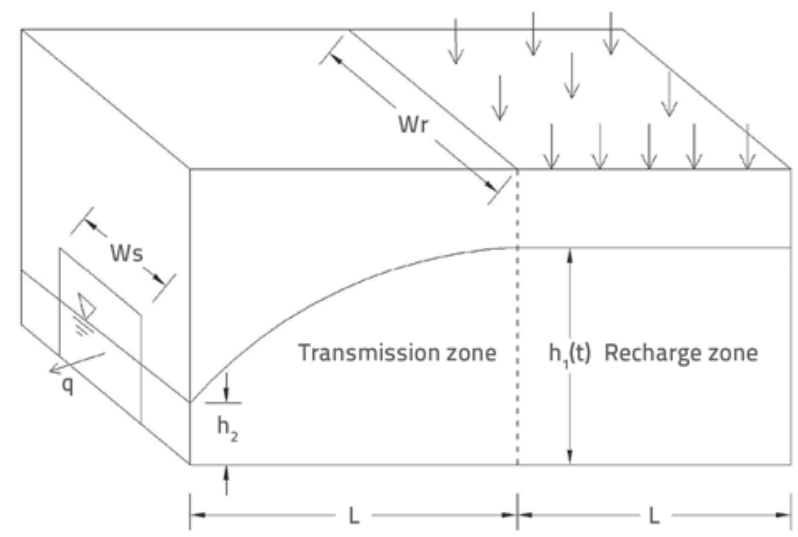

Figure 7. Conceptual model according to Bhar and Mishra [19]
The resulting hydrograph obtained using this approach (Approach 2) is shown in Figure 8 . It is plotted alongside the discharge hydrograph obtained according to the first approach (Approach 1). The groundwater level is shown in Figure 9.

The time series of seepage quantities through the Golubinka catchment was obtained by adopting $h_{1}(t)$ from Figure 9 (blue line) and $h_{2}(t)$ from Figure 3 . (Figure 10). The calculation uses the same values of $L, W_{\text {oko' }}, W_{\text {Golubinka }}$ as in the previously implemented calculation for Approach 1. The results presented in Figure 10 are obtained by using $k_{t-0 k o}=1.0 \cdot 10^{-7} \mathrm{~m} / \mathrm{s}$ (for the Oko position) and $k_{t-G O L U B I N K A}=5.3 \cdot 10^{-2} \mathrm{~m} / \mathrm{s}$ (for the Golubinka Spring position).

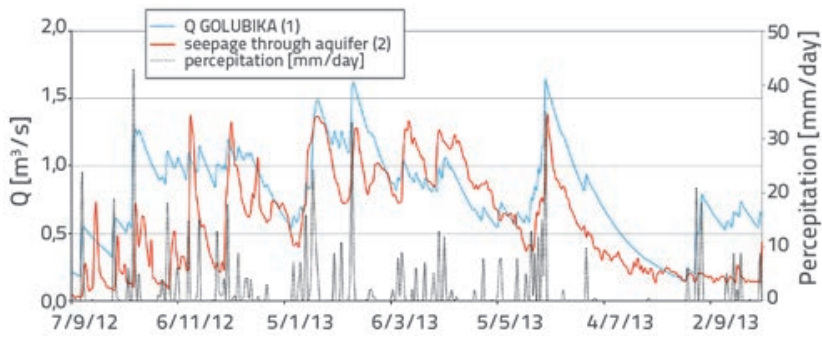

Figure 10. Time series of seepage through Golubinka catchment (groundwater flow in the aquifer) and discharge at Golubinka Spring (Approach 2)

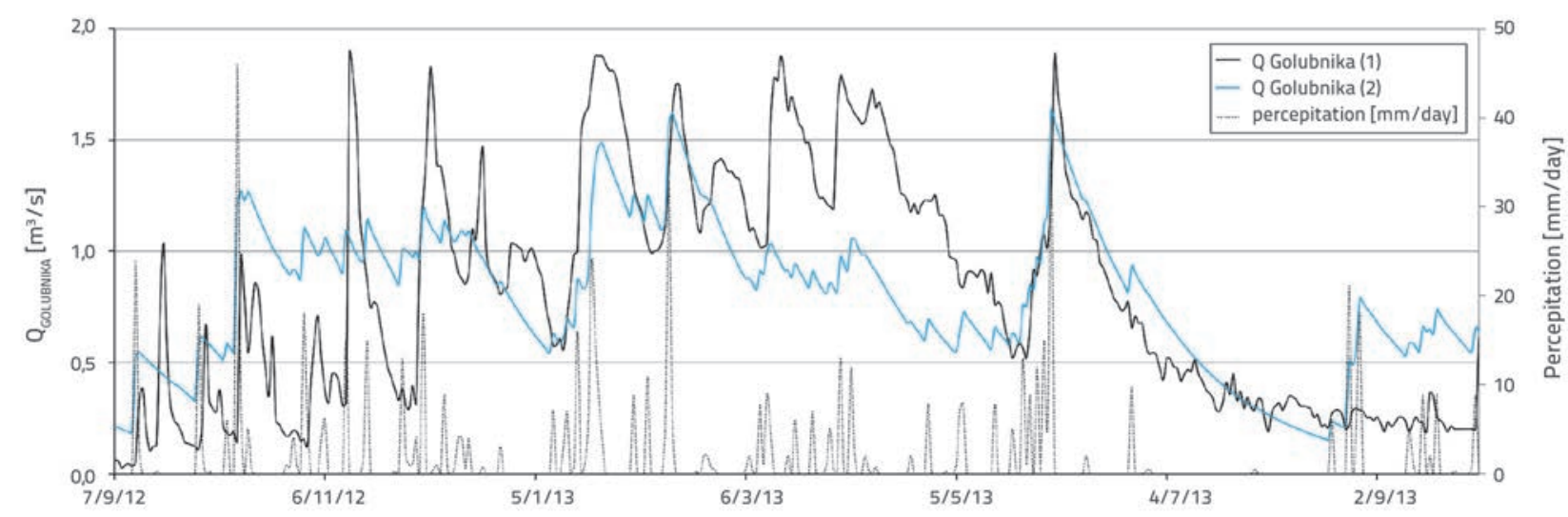

Figure 8. Discharge hydrograph for the Golubinka Spring in the analysed period (Approaches 1 and 2 )

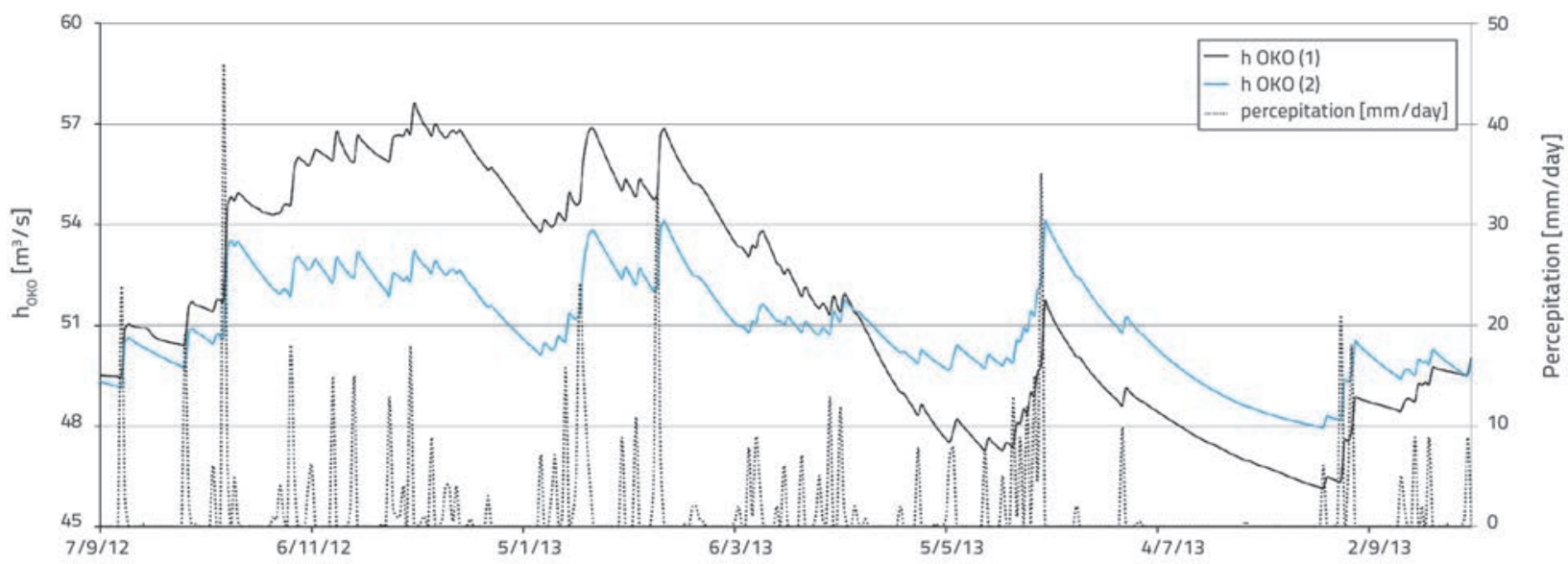

Figure 9. Groundwater levels in the analysed period at the Oko piezometer (Approaches 1 and 2) 


\section{Conclusion}

Two approaches were used for the determination of the karst spring discharge hydrograph. The first approach uses the precipitation and water level data, and the second uses the precipitation data only. Although both use the same input data for the precipitation, infiltration coefficient, effective porosity, catchment area, and geometric characteristics of the catchment, they yield different discharge hydrographs. It can be suggested, based on the comparison of results, that the spring discharge obtained using the second approach is more sensitive to precipitation. This second approach also yields more uniform discharge quantities with smaller discharge oscillations compared to the values obtained with the first approach, where intense and sudden increases of discharge were clearly discernible. These results are in accordance with those obtained by the groundwater level hydrograph. The Golubinka Spring hydrograph formed from the first approach can be strongly supported with the results of a non-linear onedimensional groundwater seepage model in a fracture system, while the results of the second approach suggest a significantly lower correlation with the nonlinear seepage model.

The results suggest that the approaches used are suitable for the evaluation of groundwater flow and groundwater levels, especially as a preliminary work for a subsequent more detailed analysis. These results also point to the need of conducting field tests, in order to obtain in-situ data necessary for calibration of groundwater flow models.

\section{REFERENCES}

[1] Bahun, S.: Geološka osnova zaštite podzemnih voda u kršu (Geological basis for water protection in karst), Geol. vjesnik, 42 (1989), pp. 201-211.

[2] Moore, C.H.: Carbonate diagenesis and porosity, Development in sedimentology, 46. Amsterdam: Elsevier, pp. 338, 1989

[3] Kiraly L.: Rapport sur I"état actuel des connaissances dans le domaines des caractères physiques des roches karstiques, In: Burger A. and Dubertret L. (Eds), Hydrogeology of karstic terrains, Int. Union of Geol. Sciences, B, 3 (1975), pp.53- 67.

[4] Cook, P.G.: A guide to regional groundwater flow in fractured aquifers, CSIRO Land and Water, Seaview Press, Henley Beach, South Australia, pp. 108, 2003.

[5] Mangin, A.: Contribution a létude hydrodynamique des aquifères karstiques. Thèse, Institut des Sciences de la Terre de l'Université de Dijon, 1975.

[6] Kresic, N.: Hydrogeology and groundwater modeling, Second edition, CRC Press, 2006

[7] Kuk, V., Prelogović, E., Dragičević, I.: Seismotectonically active zones in the Dinarides, Geol. Croatica, 53 (2000) 2, pp. 295-303.

[8] Majcen, Ž., Korolija, B.: Osnovna geološka karta SFRJ 1:100.000, List Zadar L33-139 (Basic Geological Map of the SFRY, scale 1:100.000, Zadar Sheet), Institut za geološka istraživanja Zagreb (1963-1969), Savezni geološki zavod, Beograd, 1973.

[9] Vlahović, I., Tišljar, J., Velić, I., Matičec, D.: Evolution of the Adriatic Carbonate Platform: Palaeogeography, main events and depositional dynamics, Palaeogeography, Palaeoclimatology, Palaeoecology, 220 (2005), pp. 333-360, https://doi. org/10.1016/j.palaeo.2005.01.011

[10] Fritz, F., Pavičić, A.: The Boljkovac spring, Croatia - a case of the overexploitation of a karst spring, XXIII I.A.H. Congress "Aquifer overexploitation", Proceedings, Canary Islands, Spain, pp. 515$518,1991$.
[11] Fritz, F.: Ravni kotari-Bukovica, Hidrogeološka studija (Ravni Kotari-Bukovica, Hydrogeological study), Unpublished report, Archive of the Croatian Geological Survey, Zagreb, pp. 134, 1976.

[12] Žugaj, R.: Regionalna hidrološka analiza u kršu Hrvatske (Regional Hydrological Analysis in Croatian Karst), Croatian Hydrological Society, Zagreb, 139 p., 1995.

[13] Bonacci, 0.: Monthly and annual effective infiltration coefficients in Dinaric karst: example of the Gradole karst spring catchment, Hydrological Sciences-J"ournal-des Sciences Hydrologiques, 46 (2001) 2, pp. 287-299, https://doi. org/10.1080/02626660109492822

[14] Katsanou, K., Maramathas, A., Lambrakis, N.: Simulation of Karst Springs Discharge in Case of Incomplete Time Series, Water Resour Manage, 29 (2015), pp. 1623-1633, https://doi. org/10.1007/s11269-014-0898-2

[15] IGH: Vodoistražni radovi na području Zadra - Istražno bušenje, IZV-13-015, 2013.

[16] Kovács, A.: Geometry and hydraulic parameters of karst aquifers: a hydrodynamic modeling approach, 1-131, PNR61, DN_Haute_ Ajoie, 2003.

[17] Geotehnika: Vodoistražni radovi Zadar, Knjiga II - Crpljenja i saliniteti, 1968

[18] Geotehnika: Vodoistražni radovi Zadar, Knjiga III - Vodostaji, 1968.

[19] Bhar, A.K., Mishra, G.C.: One-dimensional springflow model for time variant recharge, Hydrological Sciences-Journal-des Sciences Hydrologiques, 42 (1997) 3, pp. 381-390, https://doi. org/10.1080/02626669709492035 